\title{
Seasonal distribution of minke whales Balaenoptera acutorostrata in relation to physio- graphy and prey off the Isle of Mull, Scotland
}

\author{
Kelly Macleod $^{1,2, *}$, Richard Fairbairns ${ }^{3}$, Alison Gill ${ }^{3}$, Brenan Fairbairns ${ }^{3}$, \\ Jonathan Gordon ${ }^{1,2}$, Chris Blair-Myers ${ }^{4}$, Edward C. M. Parsons ${ }^{1}$ \\ ${ }^{1}$ Hebridean Whale and Dolphin Trust, Main Street, Tobermory, Isle of Mull PA75 6NU, UK \\ ${ }^{2}$ Sea Mammal Research Unit, University of St. Andrews, St. Andrews, Fife KY16 8LB, UK \\ ${ }^{3}$ Sea Life Surveys, Ledaig, Tobermory, Isle of Mull PA75 6NU, UK \\ ${ }^{4}$ Kent County Council, Maidstone, Kent ME14 1XQ, UK
}

\begin{abstract}
Sightings of minke whales Balaenoptera acutorostrata were recorded in waters off the Isle of Mull between March and November each year from 1992 to 1999. Survey effort amounted to $42342.5 \mathrm{~km}$, and 850 minke whale encounters were recorded. Data were analysed in relation to undersea topography and seabed sediment type using multiple logistic regression. The effect of potential minke whale prey distribution was inferred from maps predicting suitable habitats for the lesser sandeel Ammodytes marinus and herring Clupea harengus constructed using a Geographical Information System (GIS). Whale distribution changed with season, and this may be a response to a shift in prey preferences. In spring, sediment type was a significant predictor of whale presence and sightings predominated over mixtures of gravel/sand seabed sediments. This distribution closely matched that of the sandeel, which is dependent on suitable winter settlement grounds. Throughout summer, the distribution of the minke whale underwent considerable change. In June, minke whales were predominately distributed over the sandeel habitat, but in July they dispersed to the predicted pre-spawning herring habitat, clustering in that area by August. In the waters around Mull, shifts in prey distribution and abundance occur between March and November and are the most likely factor governing the distribution and abundance of the minke whale.
\end{abstract}

KEY WORDS: Minke whale $\cdot$ Bathymetry $\cdot$ Seabed sediment $\cdot$ Herring $\cdot$ Sandeel $\cdot$ Geographical Information System

Resale or republication not permitted without written consent of the publisher

\section{INTRODUCTION}

In the NE Atlantic, minke whales Balaenoptera acutorostrata range from the Barents Sea to Portugal, and east into the western Mediterranean during summer. The wintering range is poorly known but includes waters from the southern North Sea to the Straits of Gibraltar (Rice 1998). The feeding season of baleen whales generally occurs during summer and breeding during winter. Seasonal migrations may occur between the feeding and breeding grounds. There is considerable overlap between summering and wintering ranges of NE Atlantic minke whales, and some individuals reside year-round in temperate waters.

The current population estimate for the North Atlantic minke whale is thought to be in excess of 100000 (Sigurjonsson 1995). Whilst the minke whale is not an endangered species (Reeves \& Leatherwood 1994), annual losses occur from NE Atlantic stocks through direct (e.g. Bjorndal \& Conrad 1998) and indirect takes in fisheries (IWC 2003). Competition between minke whales and fishermen for commercial fish species (e.g. Schweder et al. 1998) has led to proposals for reducing the size of minke whale stocks. Additionally, chemical and acoustic 
pollution, and other forms of habitat degradation and loss, are potential threats to most cetaceans, including the minke whale (Parsons et al. 2000, Gill et al. 2001).

Effective management and conservation of cetaceans can be assisted through an understanding of the effects of environmental factors, including physical, chemical and biological factors, on their distribution and abundance. Knowledge of species habitat preferences can aid the establishment of protected areas (Hooker et al. 1999), improvement of population abundance estimates, interpretation of population trends (Forney 1999) and understanding the consequences of environmental shifts for long-term management. Many factors may influence the temporal and spatial distribution and abundance of cetaceans but few studies have investigated such links for minke whales. Water depth (Skov et al. 1995, Hooker et al. 1999), seabed sediment type (Naud et al. 2003), oceanographic fronts (Kasamatsu et al. 2000), sea-surface temperature (Kasamatsu et al. 2000, Hamazaki 2002) and the extent of sea ice (Kasamatsu et al. 2000) are known to influence minke whale distribution, although their relative importance varies geographically. Minke whale distribution and abundance on the feeding grounds will ultimately depend on the distribution of their prey, as has been demonstrated for other baleen whales (Whitehead \& Carscadden 1985, Payne et al. 1990, Woodley \& Gaskin 1996). Significant correlations between whale distribution and environmental factors may be indirect due to their influence on prey distribution. Many benthic and pelagic fishes show habitat associations throughout or during parts of their life cycle that can directly influence their survivorship and recruitment (Reay 1970, Lindholm et al. 2001, Maravelias 2001, Borja et al. 2002).

Minke whales have been described as the most icthyophagous of the Balaenoptera (Gaskin 1982). In the North Atlantic, they are known to take a range of pelagic shoaling and demersal fish species, in particular sandeel Ammodytes sp., herring Clupea harengus, mackerel Scomber scombrus, capelin Mallotus villosus, cod Gadus morhua and haddock Melanogrammus aeglefinus (Jonsgård 1982, Nordøy \& Blix 1992, Haug et al. 1995a,b). The feeding habits of most baleen whales can be categorised as skimming, swallowing or both (Hoelzel et al. 1989). Minke whales are a typical swallowing species and engulf prey concentrated in shoals, which they chase and herd from below (Hoezel et al. 1989) or locate below feeding birds (Hoezel et al. 1989, Gill et al. 2000). The lesser sandeel A. marinus and herring are prey of the minke whale in British waters (Nørdoy \& Blix 1992) and these species are known to exhibit habitat preferences in terms of bathymetry and seabed sediment type. Sandeel prefer shallow waters and seabed sediments of coarse sand and fine gravel (Macer 1966, Reay 1970, Wright \& Begg 1997). The relative abundance of herring is influenced by temperature, seabed substrate, depth and by boundaries between water masses that enhance local production and food availability (Maravelias 1997, 2000). Maravelias et al. (2000) showed that aggregations of pre-spawning herring in the northern North Sea preferred zooplankton-rich waters at depths between 100 and $150 \mathrm{~m}$. Spawning herring favour gravel beds, generally within 30 to $50 \mathrm{~km}$ of the coast (Saville \& Bailey 1980, Blaxter 1990).

Waters surrounding the Inner Hebrides off the west coast of Scotland, UK, accommodate a minke whale population in which most individuals are seasonally resident (Gill 1994) and in which some may reside year-round. Data collected by a tour operator in coastal waters of the Isle of Mull, Coll and the Small Isles off western Scotland (Fig. 1) between 1992 and 1999 were analysed to investigate the seasonal and spatial distribution of the minke whale in relation to depth, slope and seabed sediment type. In the absence of fisheries data, the influence of sandeel and herring distribution, inferred from maps of potential distribution predicted from known associations of these species with bathymetry and sediment type, is also discussed.

Part of these data (1993 to 1995) collected by the same tour operator were previously analysed by Leaper et al. (1997) to assess the relative abundance and distribution of minke whales. The potential for bias in such data sets is strong because tour operators tend to travel to areas thought to have high densities of whales. Leaper et al. (1997) divided the survey area into blocks for analysis. The purpose of the stratification was to determine the largest block size such that prior knowledge of the locations in which the whales were last found did not allow them to be found more easily in the block on subsequent trips. With a $4 \mathrm{~km}$-square block, overdispersion caused by clumping of sightings was evident in only $3 \%$ of all blocks surveyed; this was considered the maximum size of block free of bias due to prior knowledge of whale locations. This study further showed that minke whale distribution changed significantly with season. These results form the basis of the temporal and spatial stratification for this analysis.

\section{MATERIALS AND METHODS}

Data collection. Data were collected in coastal waters off the Isle of Mull, the Small Isles and Coll $\left(\sim 56^{\circ} 20^{\prime}\right.$ to $57^{\circ} \mathrm{N}$ and $6^{\circ}$ to $6^{\circ} 40^{\prime} \mathrm{W}$ ) (Fig. 1) between March and November each year from 1992 to 1999 . The data were collected on board the $12 \mathrm{~m}$ motor vessel 'Alpha Beta' run by an experienced tour operator, who had been running cetacean sighting trips in the area since 1989. 
Cetacean sightings, search effort (measured as distance travelled by the boat) and environmental variables were recorded by the tour operator (the vessel skipper) using Logger software (IFAW 1994) run on a personal computer in the wheelhouse. The skipper made observations from the wheel house ( $2 \mathrm{~m}$ eye height), an additional trained observer was on the flying bridge ( $4.5 \mathrm{~m}$ eye height) and a varying number of passengers observed from seats on the observation deck (3 m eye height). Surveying was carried out in Beaufort sea states of $\leq 4$.

Data on survey effort was collected and included the position of the vessel (NMEA 0183 serial interface between the laptop computer and the vessel Global Positioning System, GPS), start and end time of trips, and the search status throughout each trip. The

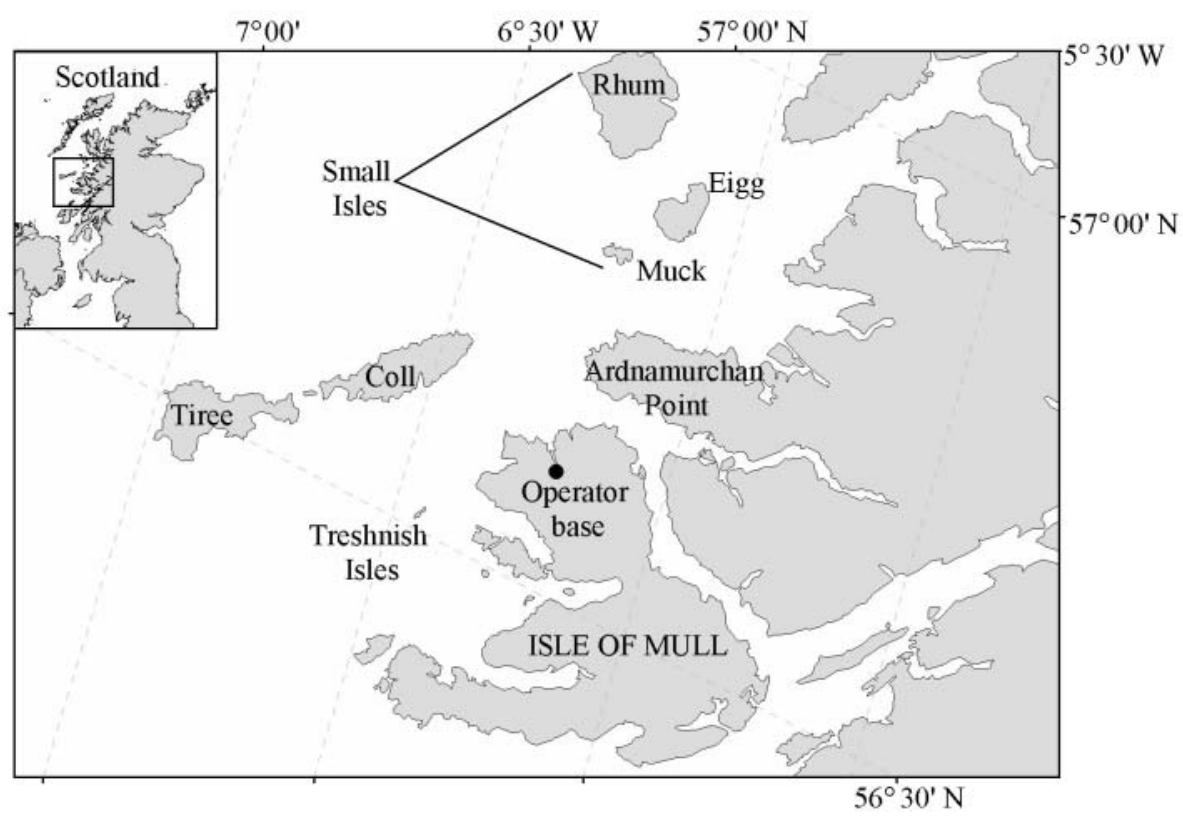

Fig. 1. Research area off Isle of Mull and wider Inner Hebrides, Scotland search status detailed whether the observers were actively searching for whales (on effort) or not (off effort). The GPS position was updated every 5 min so that the cruise track of the vessel could be plotted. Environmental data, including wind speed, wind direction and Beaufort sea state, were recorded in Logger by the skipper. Logger data were updated at regular intervals (environment) or as they changed (effort and environment). The program provided an audible prompt when the input of the environmental data was due.

When a cetacean was sighted, the time of the first sighting cue, the GPS position and visual estimates of sighting angle and bearing were recorded in Logger. The skipper entered additional information on species and certainty of identification, group size and composition (such as the presence of calves), behaviour and associations between species and sea birds.

Environmental data. Admiralty charts of the survey area were digitised using the Geographical Information System (GIS) ArcInfo 8 to produce digital terrain models of seabed slope and bathymetry. A digital map of sediment classes in the survey area was obtained from the British Geological Survey. The sediment types were reclassified: (1) $\mathrm{S}_{1}=$ gravelly sand, sandy gravel, (2) $\mathrm{S}_{2}=\mathrm{mud} / \mathrm{sand} /$ gravel, gravel $/ \mathrm{mud} /$ sand, (3) $\mathrm{S}_{3}=$ mud, sandy mud, (4) $\mathrm{S}_{4}=\mathrm{mud} / \mathrm{sand}$, sand and (5) $\mathrm{S}_{5}=$ rock. All data were imported into a GIS, ArcView 3.2 (ESRI 1999) to form the basic environmental coverages on which analyses with the minke whale sighting data were based.

The environmental coverages were used to make maps of potential habitat for sandeel and pre-spawning and spawning herring. Sandeel habitat was de-

fined as shallow waters (20 to $60 \mathrm{~m}$ ) and sediments of coarse sand and fine gravel (Macer 1966, Reay 1970, Wright \& Begg 1997). Pre-spawning herring habitat was defined as water depths of 100 to 150 m (Maravelias et al. 2000) and spawning herring habitat as areas of gravel seabed sediments (Saville \& Bailey 1980, Blaxter 1990). Using this information, the digital bathymetry and sediment data were queried using ArcView, and 3 further coverages of potential sandeel habitat and attractive areas to pre-spawning and spawning herring were produced.

Data analysis. All data from 1992 to 1999 were used in the analysis, with the exception of that collected in 1996, which were considered unreliable due to problems with the GPS and Logger.

Only positive identifications of minke whales and sightings recorded during survey effort were used in the analysis. The sightings and survey effort data were pooled over years and stratified both spatially and temporally. We defined 3 seasons: (1) spring (March, April and May), (2) summer (June, July and August), and (3) autumn (September, October and November). Spatial stratification of the survey area was used to aid visual identification of 'high use' areas by minke whales and limit bias caused by the searching behaviour of the tour operator (Leaper et al. 1997). For this study, a 2 kmsquare grid $\left(4 \mathrm{~km}^{2}\right)$ was created throughout the survey area and the data were analysed on this spatial scale. A smaller grid than suggested by Leaper et al. (1997) was used so that relationships between minke whales and environmental features on a finer scale could be investigated. Changes in seasonal distribution of the minke 
whale were investigated through the estimation of an encounter rate (number of sightings $\mathrm{km}^{-1}$ surveyed, $\mathrm{n} \mathrm{km}{ }^{-1}$ ) within each $2 \mathrm{~km}$ square-grid and for each season, and was mapped using ArcView.

To investigate the relationship between minke whale distribution and environmental parameters, each square of the $2 \mathrm{~km}$ grid was assigned a value for the following parameters: $\mathrm{MD}=$ mean depth $(\mathrm{m}) ; \mathrm{MIND}=\min$ imum depth (m); MAXD = maximum depth (m); SDD = standard deviation depth $(\mathrm{m})$ (a measure of variability within a grid square); $\mathrm{MS}=$ mean slope $(\%) ;$ MINS = minimum slope $(\%)$; MAXS $=$ maximum slope $(\%)$; SDS = standard deviation slope $(\%) ;$ and $\mathrm{S}_{1-5}=$ dominant seabed sediment type. The survey effort (E) in each grid square was also included in the analysis as a continuous variable to account for the varying survey effort.

General linear models (GLMs) can be used to fit nonnormally distributed data by expression of an appropriate link function (McCullagh \& Nelder 1989). Logistic regression (Collet 1991) was used to examine the importance of the environmental parameters on the distribution of minke whales. The encounter rate for each grid square was categorised as either 0 or 1 , signifying absence or presence of whales, respectively. Logistic regression models the probability of whale presence in a grid square given the environmental parameters. The logistic transformation (the link function) of a success probability $\mathrm{p}$ is $\log (\mathrm{p} /[1-\mathrm{p}])$, written as:

$$
\operatorname{logit}(\mathrm{p})=\beta_{0}+\beta_{1} x_{1_{\mathrm{i}}}+\beta_{2} x_{2_{\mathrm{i}}}+\ldots+\beta_{\mathrm{k}} x_{\mathrm{k}_{\mathrm{i}}}
$$

for $k$ explanatory variables $\left(x_{1^{\prime}} x_{2_{\mathrm{i}}} \ldots x_{\mathrm{ki}}\right)$ associated with that observation. On rearrangement of this equation and given $\mathrm{h}_{\mathrm{i}}=\sum_{j} \mathrm{~b}_{j} \mathrm{x}_{j_{i}} \ldots$

$$
\mathrm{p}_{\mathrm{i}}=\frac{e^{h_{\mathrm{i}}}}{1+e^{h_{\mathrm{i}}}}
$$

The data were overdispersed and a scale parameter was estimated for each model. Each environmental predictor variable was modelled in turn, and the significant variables were used to build a full model using forward selection procedures. The significance of additional variables was assessed using an analysis of deviance (Collet 1991) against the critical values of a $\chi^{2}$ distribution $(\alpha=0.05)$. Single variables significant at the $10 \%$ level were also initially retained in the model. The residual deviance was used as a measure of model fit; the smaller the deviance the better the fit of the model. The residual deviance of the final model, scaled for the estimated dispersion parameter, was tested against a $\chi^{2}$ distribution $(\alpha=0.05)$, where $\mathrm{H} 0=$ model correct, $\mathrm{H} 1=$ model not correct. The fit of the final model was also examined using diagnostic plots. Half- normal standardised deviance residuals and index plots of Cook's statistic (Collet 1991) were used to assess the adequacy of the link function and to detect outliers in the data. The analysis was carried out using Genstat 5 (Lawes Agricultural Trust 1998).

\section{RESULTS}

Between 1992 and 1999 (excluding 1996), $42342.5 \mathrm{~km}$ was surveyed on effort (Fig. 2). The total number of minke whale encounters was 850 (Table 1), comprising 1285 individuals. Whales tentatively identified as juveniles (half to three-quarter adult size) accounted for $40.5 \%$ of individuals and $5.1 \%$ of whales encountered were calves (less than half adult size). The proportion of juveniles and calves in relation to the total number of whales encountered increased from spring to autumn. The mean group size over all seasons was $1.5(\mathrm{SE}=0.9$ ). Mean group sizes differed significantly with season (Kruskal-Wallis, $\mathrm{p}<0.001$ ), tending to be larger during autumn than in the previous seasons. In spring and summer, 71.3 and $77.2 \%$ of encounters, respectively, were with single minke whales. In autumn, $55.7 \%$ of encounters were with single individuals, the remainder being pairs or larger groups of up to 10 individuals.

The effect of varying numbers of observers on the number of whales sighted was not considered in this analysis. Over all years, only $17 \%$ of sightings were recorded as first seen by passengers, and variation in the number of observers did not vary systematically. Survey effort was carried out in Sea States 0 to 4, but the greatest proportion of effort and minke whale sightings occurred during Sea State 2 or below. For data pooled over the years, the effect of sea state was not significant $(p>0.05)$ and whale counts were not adjusted prior to the calculation of encounter rates. The highest mean seasonal encounter rate occurred during autumn (Table 1) and the difference between seasons was significant (Kruskal-Wallis, p < 0.001). The trend for the highest encounter rates during late summer and autumn was consistent within years.

A change in distribution and relative abundance appeared to occur between spring and autumn (Fig. 3),

Table 1. Balaenoptera acutorostrata. Summary of minke whale sightings each season pooled over years. $\mathrm{N}_{\mathrm{a}}$ : number of adults; $\mathrm{N}_{\mathrm{j}}$ : number of juveniles; $\mathrm{N}_{\mathrm{c}}$ : number of calves; $\mathrm{N}_{\mathrm{t}}$ : total number of whales; $\mathrm{n}$ : number of encounters; L: total survey effort; $\mathrm{n} / \mathrm{L}$ : encounter rate $\left(\mathrm{n} \mathrm{km}^{-1}\right)$; s: mean group size

\begin{tabular}{|lrrrrrrrr|}
\hline Season & $\mathrm{N}_{\mathrm{a}}$ & $\mathrm{N}_{\mathrm{j}}$ & $\mathrm{N}_{\mathrm{c}}$ & $\mathrm{N}_{\mathrm{t}}$ & $\mathrm{n}$ & $\mathrm{L}(\mathrm{km})$ & $\mathrm{n} / \mathrm{L}$ & $\mathrm{s}(\mathrm{SE})$ \\
\hline Spring & 89 & 38 & 2 & 129 & 87 & 5890.3 & 0.015 & $1.5(0.10)$ \\
Summer & 463 & 339 & 36 & 838 & 596 & 28769.3 & 0.021 & $1.4(0.04)$ \\
Autumn & 146 & 144 & 28 & 318 & 167 & 7682.9 & 0.022 & $1.9(0.11)$ \\
\hline
\end{tabular}



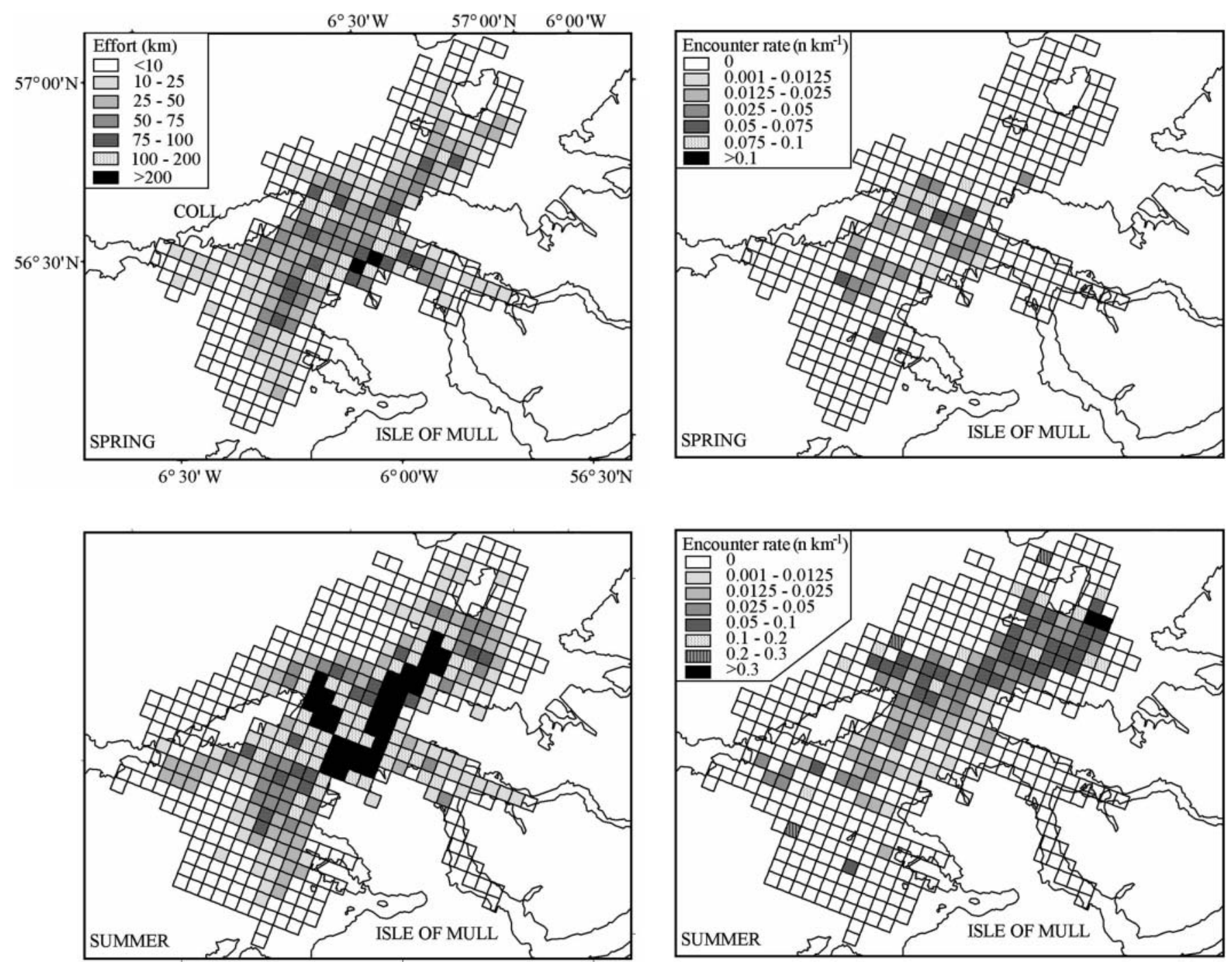

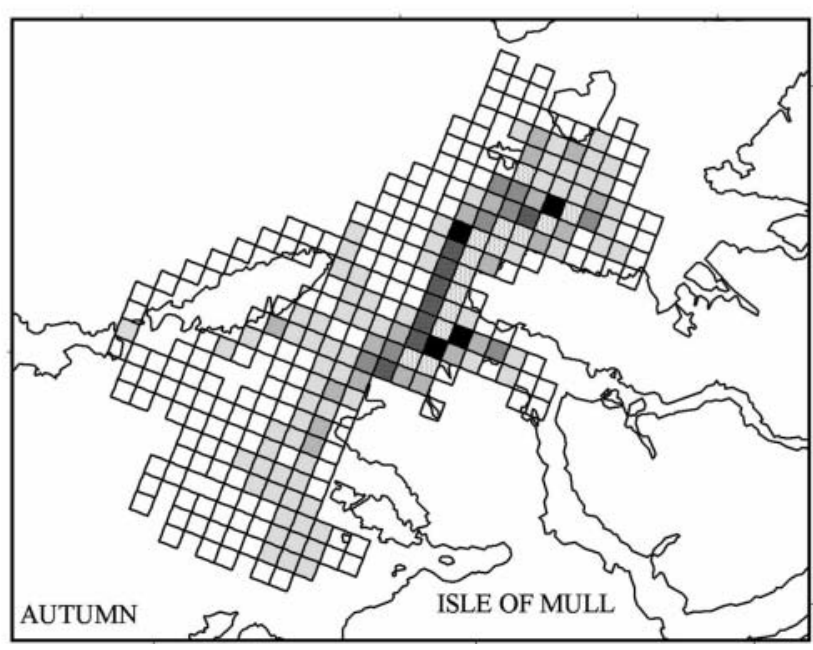

Fig. 2. Balaenoptera acutorostrata. Survey effort, as distance travelled (on a $2 \mathrm{~km}$ grid) in study area during spring (top), summer (middle) and autumn (bottom)

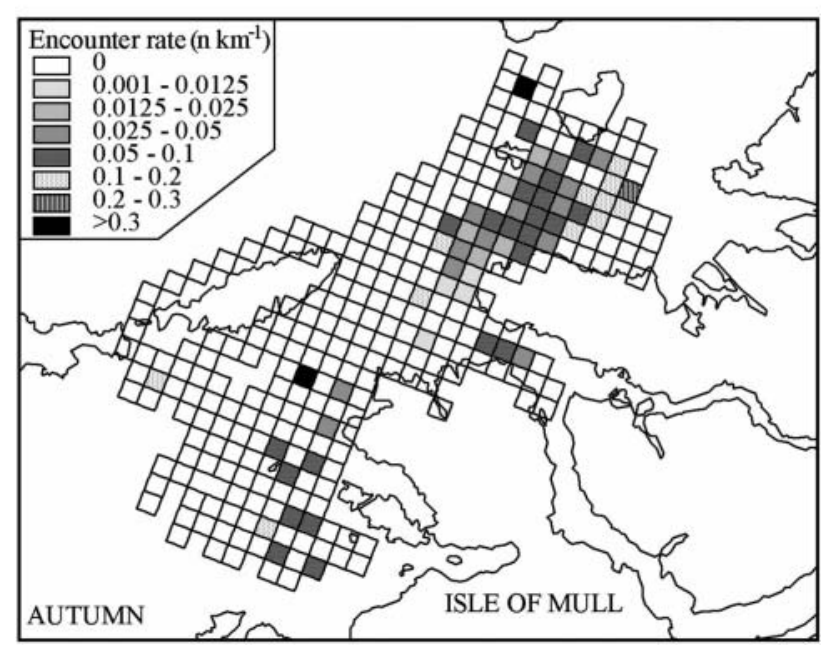

Fig. 3. Balaenoptera acutorostrata. Encounter rates (sightings $\mathrm{km}^{-1}$ ) of minke whales during spring (top), summer (middle) and autumn (bottom) 
Table 2. Significant environmental variables predicting presence of minke whales Balaenoptera acutorostrata (logistic regression). D: residual deviance; S1 to S5: seabed types (see second subsection of 'Materials and methods' for details)

\begin{tabular}{|c|c|c|c|c|c|c|c|c|c|c|c|c|}
\hline \multirow{2}{*}{ Variable } & \multicolumn{4}{|c|}{ Spring $\longrightarrow$} & \multirow[b]{2}{*}{ Antilog $\beta$} & \multicolumn{3}{|c|}{ - Summer } & \multirow[b]{2}{*}{ Antilog $\beta$} & \multicolumn{2}{|c|}{ - Autumn - } & \multirow[b]{2}{*}{$\mathrm{p}$-value } \\
\hline & Antilog $\beta$ & df & $\mathrm{D}$ & p-value & & df & $\mathrm{D}$ & $\mathrm{p}$-value & & df & $\mathrm{D}$ & \\
\hline Constant & 0.072 & 299 & 250.1 & & 0.436 & 447 & 550.0 & & 0.259 & 286 & 290.6 & \\
\hline Effort (E) & 1.004 & 298 & 178.1 & 0.000 & 1.018 & 446 & 409.9 & 0.000 & 1.025 & 285 & 244 & 0.000 \\
\hline \multicolumn{13}{|l|}{ Sediment (S) } \\
\hline S1 & 1.000 & & & & 1.000 & & & & 1.000 & & & \\
\hline $\mathrm{S} 2$ & 0.300 & & & & 0.877 & & & & 0.001 & & & \\
\hline S3 & 0.000 & 295 & 188.3 & 0.000 & 0.360 & 443 & 486 & 0.000 & 2.678 & 282 & 261.4 & 0.000 \\
\hline $\mathrm{S} 4$ & 0.000 & & & & 0.629 & & & & 2.604 & & & \\
\hline S5 & 0.105 & & & & 0.059 & & & & 0.212 & & & \\
\hline \multicolumn{2}{|l|}{ Mean depth (MD) } & & & & 1.014 & 441 & 529.6 & 0.002 & 1.014 & 284 & 282.8 & 0.012 \\
\hline \multicolumn{2}{|l|}{ Min. depth (MIND) } & & & & 1.012 & 441 & 537.4 & 0.050 & & & & \\
\hline \multicolumn{2}{|l|}{ Max. depth (MAXD) } & & & & 1.006 & 441 & 539.3 & 0.098 & 1.010 & 284 & 279.9 & 0.003 \\
\hline \multicolumn{2}{|l|}{$\begin{array}{l}\text { Standard deviation } \\
\text { depths (SDD) }\end{array}$} & & & & & & & & 0.039 & 284 & 282 & 0.008 \\
\hline Mean slope (MS) & 0.853 & 298 & 244.5 & 0.018 & & & & & 1.040 & 285 & 288.2 & 0.065 \\
\hline \multicolumn{2}{|l|}{ Min. slope } & & & & 2.962 & 446 & 538.9 & 0.001 & & & & \\
\hline Max. slope & 0.948 & 298 & 243.8 & 0.012 & & & & & & & & \\
\hline $\begin{array}{l}\text { Standard deviation } \\
\text { slope (SDS) }\end{array}$ & n 0.779 & 298 & 244.5 & 0.018 & & & & & & & & \\
\hline \multicolumn{2}{|l|}{$\mathrm{E} \times \mathrm{MD}$} & & & & 1.001 & 433 & 328.4 & 0.000 & & & & \\
\hline \multicolumn{2}{|l|}{$\mathrm{E} \times \mathrm{MIND}$} & & & & 1.001 & 433 & 351.1 & 0.000 & & & & \\
\hline \multicolumn{13}{|l|}{$\mathrm{E} \times \mathrm{S}$} \\
\hline \multicolumn{2}{|l|}{ S1 } & & & & 1.000 & & & & & & & \\
\hline \multicolumn{2}{|l|}{$\mathrm{S} 2$} & & & & 1.015 & & & & & & & \\
\hline \multicolumn{2}{|l|}{ S3 } & & & & 1.017 & 430 & 346.3 & 0.000 & & & & \\
\hline \multicolumn{2}{|l|}{$\mathrm{S} 4$} & & & & 1.050 & & & & & & & \\
\hline \multicolumn{2}{|l|}{ S5 } & & & & 0.992 & & & & & & & \\
\hline \multicolumn{13}{|l|}{$\mathrm{S} \times \mathrm{MD}$} \\
\hline & & & & 1.000 & & & & & & & \\
\hline \multicolumn{2}{|l|}{$\mathrm{S} 2$} & & & & 0.962 & & & & & & & \\
\hline \multicolumn{2}{|l|}{ S3 } & & & & 0.961 & 430 & 359.3 & 0.019 & & & & \\
\hline $\mathrm{S} 4$ & & & & & 0.977 & & & & & & & \\
\hline S5 & & & & & 1.042 & & & & & & & \\
\hline $\mathrm{SDD} \times \mathrm{MS}$ & & & & & & & & & 0.987 & 276 & 202.4 & 0.010 \\
\hline MAXD × MS & & & & & & & & & 0.997 & 276 & 203.9 & 0.024 \\
\hline $\mathrm{MAXD} \times \mathrm{SDD}$ & & & & & & & & & 0.999 & 276 & 204.4 & 0.032 \\
\hline
\end{tabular}

with a noticeable shift in distribution from the area between North Coll and Ardnamurchan in spring to the channel between Ardnamurchan headland and the Small Isles (Rhum, Muck and Eigg) in autumn. Environmental factors and ultimately prey distribution may be influencing this. Behaviour consistent with feeding activity, such as lunges through fish shoals, was observed during $27.5 \%$ of the minke whale encounters. During all seasons, the variable that on its own had the greatest predictive power was the amount of survey effort in each grid square (E). Subsequent environmental parameters were fitted allowing for the effects of survey effort. Sediment type was also significant in all seasons (Table 2).

During spring, a further 3 variables, MAXS, MS and SDS were, singly, significant predictors of the presence of whales (Table 2). However, a 2-term model containing just $\mathrm{E}$ and $\mathrm{S}$ was the best fit of the data $\left(\chi^{2}\right.$, $\mathrm{p}=0.492)$ :

$$
\operatorname{logit}(\mathrm{p})_{\mathrm{Mw}_{\text {spring }}}=\beta+\beta_{1} \mathrm{E}+\beta_{2} \mathrm{~S}
$$

where $\beta$ is a constant and $\beta_{1}$ and $\beta_{2}$ are parameter estimates for survey effort and sediment class. The parameter estimates (Table 3 ) show that $\mathrm{S}_{1}$, gravelly sand, seabed sediment, is the strongest predictor of the presence of a minke whale within any grid square compared to other sediments. Sediments of mud/sand/ gravel $\left(\mathrm{S}_{2}\right)$ are also an important predictor, but to a lesser extent than $\mathrm{S}_{1}$. Seabed sediment is likely to have an indirect influence on minke whale distribution, possibly through its influence on sandeel distribution. Fig. 4 shows the distribution of minke whale sightings 
during spring in relation to predicted sandeel habitat. The majority of the sightings are within a single sediment type (gravelly sand) and within depths of less than $60 \mathrm{~m}$.

A number of environmental variables were, singly, significant predictors of minke whale occurrence during the summer (Table 2). In addition to E and S, MINS, $M D, M I N D$ and MAXD were significant. MAXD and MD were strongly correlated $(p<0.001)$ and, as the less significant predictor variable, MAXD was therefore eliminated from further analysis. At the $5 \%$ level, 3 interaction terms, E with S, MD and MIND, were also significant. The interaction between $\mathrm{E}$ and $\mathrm{MD}$ was the most significant and only the interaction between $\mathrm{E}$ and $\mathrm{S}$ was significant when added to this. The final model $\left(\chi^{2}, \mathrm{p}=0.504\right)$ was:

$\operatorname{logit}(\mathrm{p})_{\mathrm{MW}_{\text {summer }}}=$
$\quad \beta+\beta_{1} \mathrm{E}+\beta_{2} \mathrm{~S}+\beta_{3} \mathrm{MD}+\beta_{4} \mathrm{E} \times \mathrm{MD}+\beta_{5} \mathrm{E} \times \mathrm{S}$

Of the dominant sediment types, the probability of minke whale presence was greatest in areas of $\mathrm{mud} / \mathrm{sand} /$ gravel mixtures $\left(\mathrm{S}_{2}\right)$. Deeper waters also increased the probability of whale occurrence (Table 3 ). During summer, particularly July, a number of known prey species, such as sprat Sprattus sprattus and mackerel, are abundant in the survey area. The range of environmental variables which, used singly, were significant predictors of whale presence may indicate that minke whales do not have a strong habitat (and therefore prey) preference during summer. Alternatively, the patterns of whale distribution between June and

Table 3. Summary of parameter estimates for final multiple logistic regression models of significant variables for each season

\begin{tabular}{|lccc|}
\hline Variables & Spring (SE) & Summer (SE) & Autumn (SE) \\
\hline Constant & $0.106(0.258)$ & $0.311(0.352)$ & $0.015(0.618)$ \\
Effort & $1.029(0.004)$ & $0.991(0.004)$ & $1.025(0.004)$ \\
Dominant sediment & & & \\
S $_{1}$ & 1.000 & 1.000 & 1.000 \\
$\mathrm{~S}_{2}$ & $0.700(0.579)$ & $2.754(0.679)$ & $0.001(9.33)$ \\
$\mathrm{S}_{3}$ & $0.000(10.2)$ & $1.112(0.461)$ & $2.863(0.373)$ \\
$\mathrm{S}_{4}$ & $0.000(13.3)$ & $0.801(0.544)$ & $1.481(0.464)$ \\
$\mathrm{S}_{5}$ & $0.164(0.520)$ & $0.121(0.550)$ & $0.215(0.707)$ \\
Mean depth & & $0.987(0.069)$ & \\
SDD & & & $1.142(0.036)$ \\
Mean slope & & & $1.271(0.143)$ \\
SDD $\times$ MS & & & $0.987(0.005)$ \\
E $\times$ MD & & $1.001(0.000)$ & \\
E $\times S$ & & & \\
$S_{1}$ & & 1.000 & \\
$S_{2}$ & & $0.980(0.015)$ & \\
$S_{3}$ & & $0.990(0.010)$ & \\
$S_{4}$ & & $1.024(0.014)$ & \\
$S_{5}$ & & $1.010(0.004)$ & \\
& & & \\
\hline
\end{tabular}

August (Fig. 5) could be explained in terms of a shift in prey preference from sandeel at the beginning of summer to herring towards the end of the season.
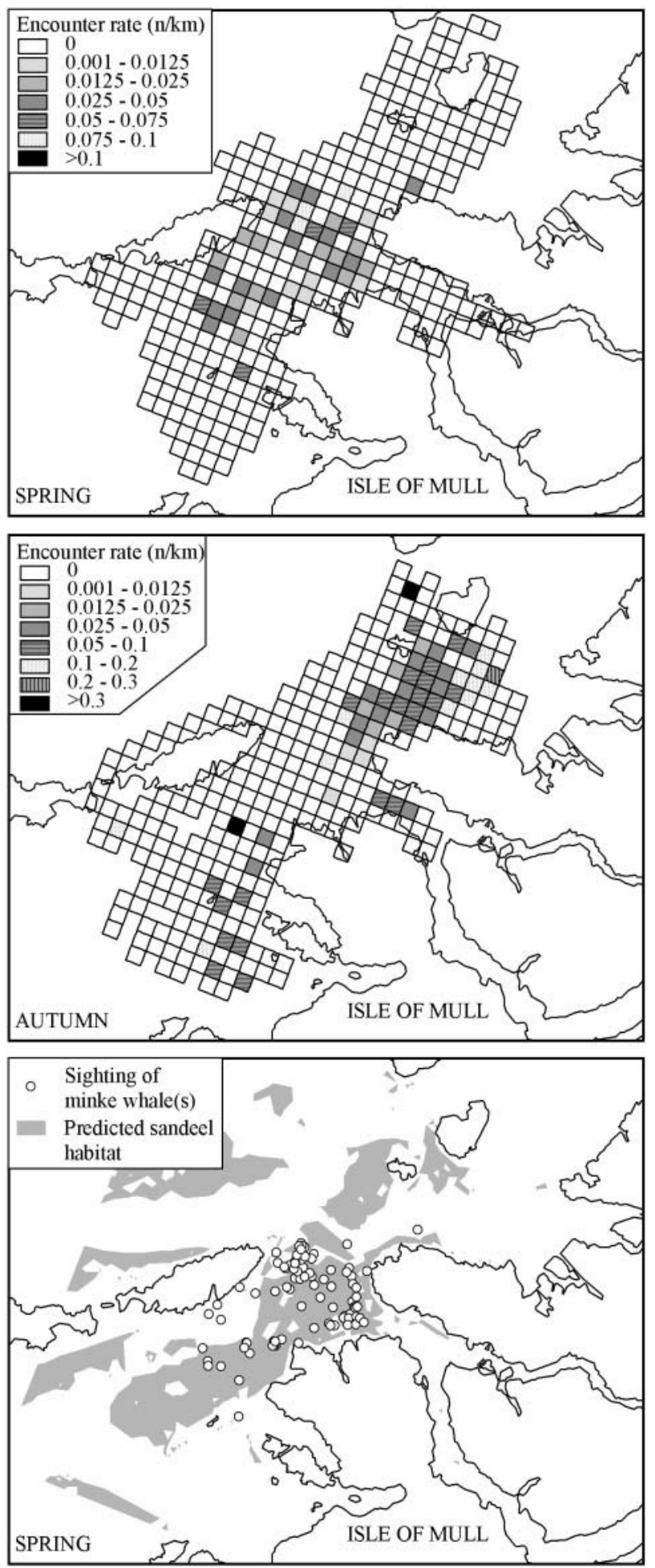

Fig. 4. Balaenoptera acutorostrata. Minke whale sightings during spring as a function of predicted sandeel habitat 
During autumn, SDD, MAXD, MD and MS were significant predictors of minke whale presence in addition to $\mathrm{E}$ and $\mathrm{S}$. There were 3 significant interactions:
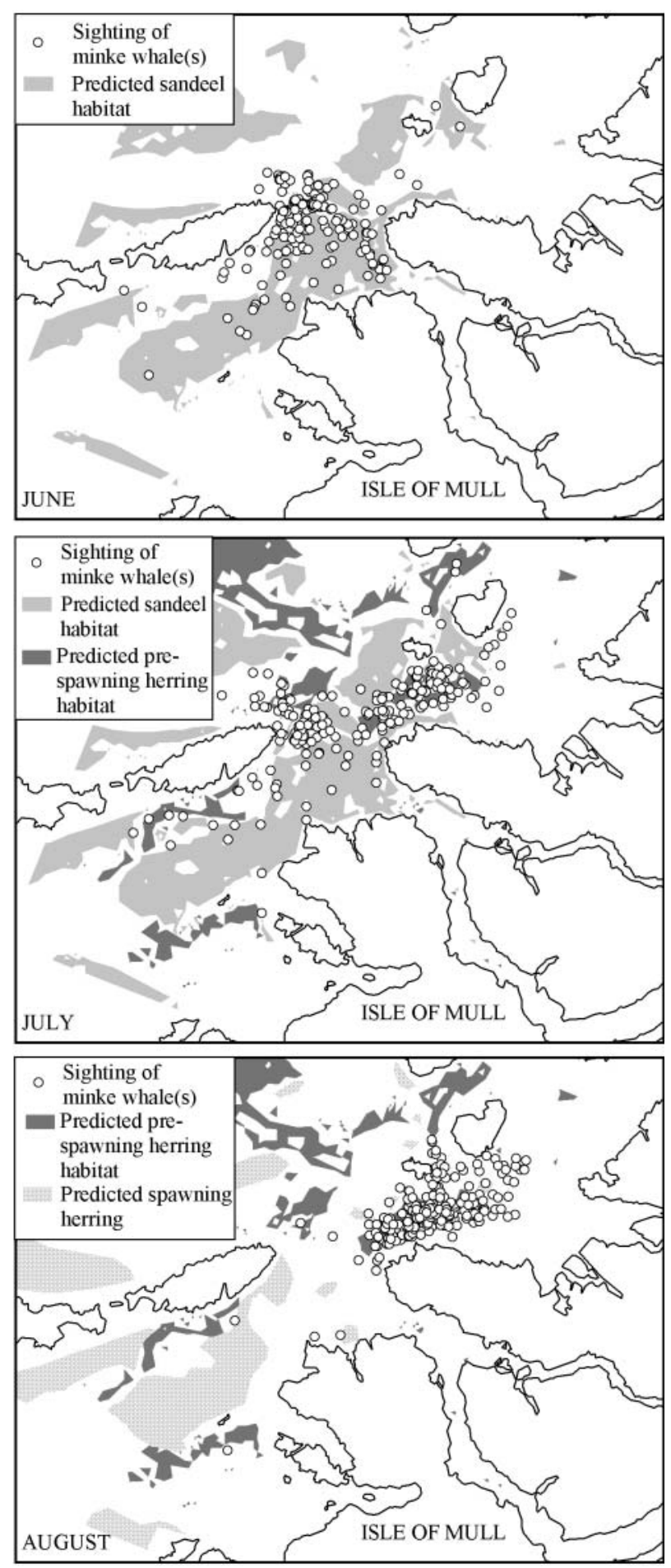

Fig. 5. Balaenoptera acutorostrata. Changes in distribution of sightings during summer months (June, July and August) as a function of predicted sandeel and herring habitats
MAXD and both SDD and MS, and SDD and MS (Table 2). The interaction between SDD and MS was the most significant and the 2 other interactions did not reduce the deviance significantly when added to the model, and were thus eliminated. The final model $\left(\chi^{2}, \mathrm{p}=0.488\right)$ was:

$\operatorname{logit}(\mathrm{p})_{\mathrm{MW}_{\text {autumn }}}=$

$$
\beta+\beta_{1} E+\beta_{2} \mathrm{~S}+\beta_{3} \mathrm{SDD}+\mathrm{b}_{4} \mathrm{MS}+\mathrm{b}_{5} \mathrm{SDD} \times \mathrm{MS}
$$

The parameter estimates (Table 3 ) indicate that the probability of encountering a minke whale was increased in areas with mud or sandy mud sediments $\left(\mathrm{S}_{3}\right)$ and where SDD and MS was greater, perhaps indicative of areas of variable seabed topography. Most autumn sightings with minke whales were in areas predicted to be suitable for pre-spawning herring (Fig. 6) and thus predation by minke whales on this species in autumn is a possible explanation for the spatial distribution of whales. Feeding on bait balls of juvenile herring has been observed during September in the survey area (A. Gill pers. comm.).

\section{DISCUSSION}

A shift in the spatial and temporal distribution of the minke whale was apparent in the Hebridean waters off the Isle of Mull (Fig. 3). In spring, minke whales were distributed predominantly between Ardnamurchan and Coll. During summer, the whales appeared to disperse over a wider area extending as a 'corridor' of higher encounter rates between the north of Coll and the east of Muck and Eigg. Finally, a concentration of whales southeast of Muck and Eigg predominated in

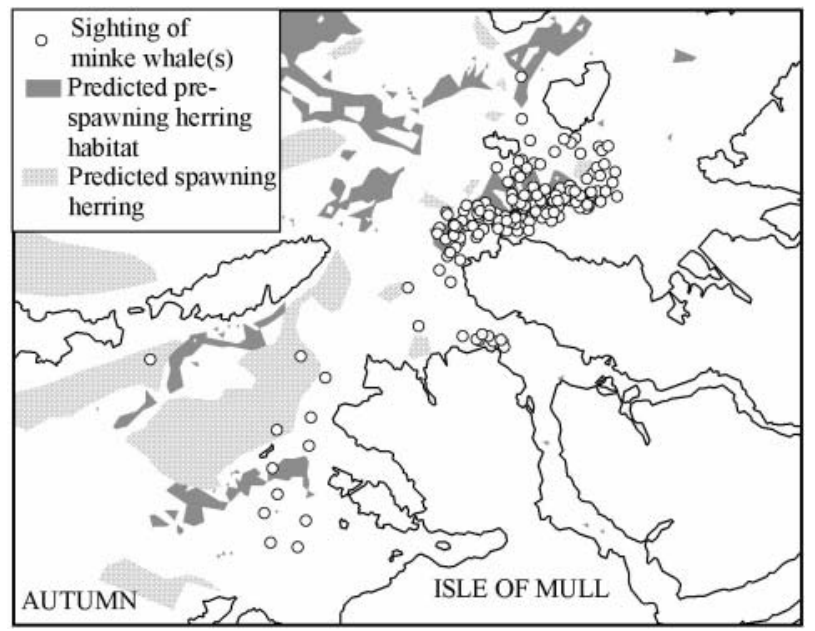

Fig. 6. Balaenoptera acutorostrata. Minke whale sightings during autumn as a function of predicted herring pre-spawning and spawning habitats 
the autumn, with a few scattered areas of high encounters in the southern region of the Treshnish Isles. The encounter rates suggest that the relative abundance of the minke whale reaches a peak during the end of summer and beginning of autumn annually.

Minke whales are present off the Island of Mull and wider Inner Hebrides throughout summer, the main feeding season for baleen whales. During this period, their distribution changes, and this may be a response to changing prey availability. The minke whale diet is flexible, varying spatially and temporally. A strong correlation exists between prey availability and minke whale diet (Haug et al. 1995, Tamura \& Fujise 2002).

In spring, the environmental variable with the most influence on the presence of minke whales was sediment type, in particular gravel/sand mixtures, with small quantities of mud and rock. The distribution of whale sightings compared well with the expected inferred distribution of sandeels during the spring (Fig. 4). Sandeels are a schooling fish, are of high calorific value (Hislop et al. 1991) and are eaten by a range of marine predators. Sandeels burrow into the seabed from October to early April, with the exception of a short period between December and January when they emerge to spawn. Sandeel distribution is restricted by their dependence on suitable settlement grounds and the most favourable sediments include clean, coarse sands or fine gravel (Reay 1970). In the North Sea, Ammodytes marinus is most abundant in depths of 20 to $40 \mathrm{~m}$ (Macer 1966). During April and May, 1-group and older sandeels emerge from the seabed to feed in the water column. They retreat to the sediment as a form of defence, which binds them to the sediments from which they emerged. The 0-group sandeels disperse over wider areas than the older age classes (P. J. Wright pers. comm.). Therefore, during spring, sandeels are available in the water column as prey to minke whales. The local sandeel fishery coincides with this timing, starting in April and finishing in mid-July ( $\mathrm{H}$. Allen pers. comm.). Minke whales off the Mingan Islands in the Gulf of St. Lawrence were sighted more frequently over sand dunes, where their 2 main prey items, sandeels and spawning capelin, were abundant (Naud et al. 2003). A link between sandeel distribution and other marine predators has been established, including the common guillemot Uria aalge (Wright \& Begg 1997), the humpback whale Megaptera novaeangliae (Payne et al. 1986) and the fin whale Balaenoptera physalus (Overholtz \& Nicolas 1979).

The summer distribution of minke whales may represent a shift in dietary preference from one prey to another as the season progresses. The whales are distributed widely in the research area; this may be a response to increased prey availability, with 2 abun- dant species, sandeels and herring, dominating the diet in early and late summer, respectively. Stockin et al. (2001) noted significant differences in the surfacing intervals of minke whales off Mull between April and October. This was interpreted as a result of changes in the foraging strategies of minke whales during this period. The spatial distribution of whale sightings appears to correlate with the likely sandeel distribution in June and the pre-spawning herring habitat in August (Fig. 5). During July, many prey species are abundant and minke whales may not have strong prey preferences at this time, as reflected in the range of single environmental predictor variables significant for the summer season.

The distribution of whales during August, southeast of the islands of Muck and Eigg, is maintained into the autumn (September to November) and is possibly linked to a continuation of feeding on pre-spawning herring. The waters of the Inner Hebrides are nursery grounds for herring, but minke whales target certain age classes (Haug et al. 2003) and may only feed on schools that have reached a certain threshold density. Small prey that occurs in dense schools is probably easier to catch. The energy density of herring, like other fish species, varies seasonally but reaches a peak in September (Mårtensson et al. 1996). Off Mull, herring form large schools and spawn during late August through October, but begin to congregate near the spawning grounds about 2 mo before this time. They move to deeper, cooler waters below the thermocline and undertake diurnal vertical migrations. Their daily migration may be a response to that of Calanus finmarchicus, their main food, which also moves into deeper, cooler waters beneath the thermocline during summer and autumn (Maravelias \& Reid 1997). This may explain the preference of minke whales for deeper waters east of Muck during late summer and autumn (Fig. 6). Herring also school in areas of increased productivity (Maravelias et al. 2000). Increased mixing in the vicinity of the Small Isles occurs due to the confluence of fresher coastal water north of Ardnamurchan and close to the south coast of Skye, with the coastal current as this travels northward. Additionally, the surrounding islands, headlands and channels increase mixing and may enhance productivity in this area (Pingree \& Maddock 1985). Topographic fronts can also form in the lee of islands and headlands and are often the location of enhanced primary and secondary production (Simpson et al. 1982). The final model of the autumn data highlighted the significance of areas of high topographic relief. Varied seabed topography can also enhance productivity. The predominance of herring in the minke whale diet in areas of the NE Atlantic is well known (Nordøy \& Blix 1992, Mårtensson et al. 1996, Lindstrøm et al. 1999). 
The apparent increase in group sizes in autumn may be a response to the abundant prey and large school sizes of herring.

The searching behaviour of the tour boat is a potential source of bias in these data. As a commercial venture, the boat tends to search areas where cetaceans have been encountered before. The importance of this variable was reflected in the significance of survey effort in each grid square in all models. Attempts to limit this bias were made by modelling environmental variables to allow for the effects of survey effort. The index of abundance was also chosen such that survey effort was the denominator of the encounter rate; thereby relative abundance between grid squares would be comparable. Finally, the data were spatially stratified on the basis of the results presented in Leaper et al. (1997) to minimise bias caused by searching behaviour of the tour operator.

This study suggests that 2 areas contained concentrations of minke whales for most of the tour operator's season. The area north of Coll had relatively high encounter rates throughout spring and summer. It did not seem to be of importance in autumn; however survey effort was low in this season. The area between Muck and Ardnamurchan was used throughout summer, but in particular during autumn. On this basis, these 2 areas may be considered as being of particular importance to minke whales in this area, a conclusion also drawn by Leaper et al. (1997). Evidence of territoriality in minke whales was proposed by Dorsey (1983) from studies of identified minke whales in the coastal waters of Washington State. The whales formed 3 distinct groups and each occupied a 'home-range' which adjoined but did not overlap with the ranges of the other groups of whales. Future research of the habitat use of identified minke whales in the Mull area could be used to investigate whether the 2 high-use areas identified represent core ranges for different, but consistent, groups of minke whales during the tour operator's season. However, the photo-identification catalogue for this area is relatively small, with few resightings, and currently does not allow such analysis. Alternatively, differences in the arrival time and usage of the area around Mull for feeding may vary with changing proportions of age and sex classes from spring to autumn, explaining the observed changes in distribution. The results from marking experiments off Svalbard and Norway have shown that females arrive at the feeding grounds before males (Christensen \& Rørvik 1980). In the Antarctic, females generally occur at higher latitudes than males during the feeding season (Ohsumi \& Masaki 1975).

At present there are limited threats to minke whales in these waters, but increased understanding of this species ecology could be important in the future. Com- parable studies on minke whales and environmental variables in the wider Hebridean waters would be of use in determining on a wider geographical scale the stability of those environmental parameters identified as important in this study.

Acknowledgements. This work was funded by a grant from the Worldwide Fund for Nature (UK) and was part of a $\mathrm{PhD}$ study at the University of Greenwich, London. We thank Dr. D. Jeffries, Natural Resources Institute and Dr. P. Hammond, Sea Mammal Research Unit, for advice on the analysis of these data. Thanks to reviewers of previous drafts of this paper-Professor J. Mathews and F. Hansen of the Hebridean Whale and Dolphin Trust and Professor D. Thomas, Natural Resources Institute. Thanks to H. Allen, Northwest Fisheries Association, for specific details on local fish distributions and to Dr. P. Wright for information on sandeel distribution. The Logger program was funded and developed by the International Fund for Animal Welfare. Admiralty charts were digitised by permission of the Controller of Her Majesty's Stationary Office and the UK Hydrographic Office. Helpful comments on the manuscript were given by 3 anonymous reviewers.

\section{LITERATURE CITED}

Bjorndal T, Conrad JM (1998) A report on the Norwegian minke whale hunt. Mar Pollut 22:161-174

Blaxter JHS (1990) The herring. Biologist 37:27-31

Borja A, Uriarte A, Egana J (2002) Environmental factors and recruitment of mackerel Scomber scombrus L. 1758 along the north-east Atlantic coasts of Europe. Fish Oceanogr 11:116-127

Christensen I, Rørvik CJ (1980) Results from markings of minke whales in the northeast Atlantic. Rep Int Whal Comm 30:201-203

Collet D (1991) Modelling binary data, 3rd edn. Chapman \& Hall, London

Dorsey EM (1983) Exclusive adjoining ranges in individually identified minke whales (Balaenoptera acutorostrata) in Washington State. Can J Zool 61:174 - 181

ESRI (Environmental Systems Research Institute) (1999) ArcView GIS 3.2. Environmental Systems Research Institute, Redlands, CA

Forney KA (1999) Trends in harbour porpoise abundance off central California, 1986-1995: evidence for interannual changes in distribution. J Cetacean Res Manag 1(1):73-80

Gaskin DE (1982) The ecology of whales and dolphins. Heinemann Educational Books, London

Gill A (1994) The photoidentification of the minke whale (Balaenoptera acutorostrata) off the Isle of Mull, Scotland. MSc thesis, University of Aberdeen, Scotland

Gill A, Fairbairns BR, Fairbairns RS (2000) Some observations of minke whale (Balaenoptera acutorostrata) feeding behaviour and associations with seabirds in the coastal waters of the Isle of Mull. Eur Res Cetaceans 13:61-64

Gill A, Reid RJ, Fairbairns BR (2001) Photographic and strandings data highlighting the problem of marine debris and creel rope entanglement to minke whales (Balaenoptera acutorostrata) and other marine life in Scottish waters. Eur Res Cetaceans 14:173-178

Hamazaki T (2002) Spatiotemporal prediction models of cetacean habitats in the mid-western North Atlantic Ocean (from Cape Hatteras, North Carolina, USA to Nova Scotia, Canada). Mar Mamm Sci 18:920-939 
Haug T, Gjøsæter H, Lindstrøm U, Nilssen K (1995a) Diet and food availability for northeast Atlantic minke whales (Balaenoptera acutorostrata) during the summer of 1992. ICES J Mar Sci 52:77-86

Haug T, Gjøsæter H, Lindstrøm U, Nilssen KT, Rottingen I (1995b) Spatial and temporal variations in Northeast Atlantic minke whale Balaenoptera acutorostrata feeding habits. In: Blix AS, Walloe L, Ulltang Ø (eds) Whales, seals, fish and man. Elsevier Science, Amsterdam

Haug T, Lindstrøm U, Nilssen KT (2003) Variations in minke whale (Balaenoptera acutorostrata) diet and body condition in response to ecosystem changes in the Barents Sea. Sarsia 87:409-422

Hislop JRG, Harris MP, Smith JGM (1991) Variation in calorific value and total energy content of the lesser sandeel Ammodytes marinus and other fish preyed on by seabirds. J Zool 224:501-517

Hoelzel AR, Dorsey EM, Stern SJ (1989) The foraging specializations of individual minke whales. Anim Behav 38: 786-794

Hooker SK, Whitehead H, Gowans S (1999) Marine protected area design and the spatial and temporal distribution of cetaceans in a submarine canyon. Consen Biol 13:592-602

IFAW (International Fund for Animal Welfare) (1994) Logger software. International Fund for Animal Welfare, PO Box 193, 411 Main Street, Yarmouth Port, MA 02675

IWC (International Whaling Commission) (2003) Annex J: report of the sub-committee on the estimation of bycatch and other human-induced mortality. In: IWC/55/Rep1 of the IWC Scientific Committee. International Whaling Commission, Impington, Cambridge, UK

Jonsgard $\AA$ (1982) The food of minke whales (Balaenoptera acutorostrata) in northern North Atlantic waters. Rep Int Whal Comm 32:259-262

Kasamatsu F, Ensor P, Joyce GG, Kimura N (2000) Distribution of minke whales in the Bellingshausen and Amundsen Seas $\left(60^{\circ}-120^{\circ} \mathrm{W}\right)$ with special reference to environmental/physiographic variables. Fish Oceanogr 9:214-223

Lawes Agricultural Trust (1998) Genstat 5, release 4.1, 3rd edn. Institute of Arable Crops Research (IACR), Rothamsted, UK

Leaper R, Fairbarns R, Gordon J, Hiby A, Lovell P, Papastavrou V (1997) Analysis of data collected from a whalewatching operation to assess relative abundance and distribution of the minke whale (Balaenoptera acutorostrata) around the Isle of Mull Scotland. Rep Int Whal Comm 47: $505-511$

Lindholm JB, Auster PJ, Ruth M, Kaufman L (2001) Modeling the effects of fishing and implications for the design of marine protected areas: juvenile fish responses to variations in seafloor. Cons Biol 15:424-437

Lindstrom U, Haug T, Rottingen I (1999) Consumption of herring, Clupea harengus, by minke whales, Balaenoptera acutorostrata, in the Barents Sea. Document SC/51/E8 presented to the IWC Scientific Committee 1999. International Whaling Commission, Impington, Cambridge, UK

Macer CT (1966) Sandeels (Ammodytidae) in the south-western North Sea; their biology and fishery. Fish Investig Ser II Mar Fish GB Minist Agric Fish Food 24:1-55

Maravelias CD (1997) Trends in abundance and geographic distribution of North Sea herring in relation to environmental factors. Mar Ecol Prog Ser 159:151-164

Maravelias CD (2001) Habitat associations of Atlantic herring in the Shetland area: influence of spatial scale and geographic segmentation. Fish Oceanogr 10:259-267

Maravelias CD, Reid DG (1997) Identifying the effects of oceanographic features and zooplankton on pre-spawning herring abundance using generalized additive models. Mar Ecol Prog Ser 147:1-9

Maravelias CD, Reid DG, Swartzman G (2000) Seabed substrate, water depth and zooplankton as determinants of the prespawning spatial aggregation of North Atlantic herring. Mar Ecol Prog Ser 195:249-259

Mårtensson PE, Lager Gotaas AR, Nordøy ES, Blix AS (1996) Seasonal changes in energy density of prey of northeast Atlantic seals and whales. Mar Mamm Sci 12:635-640

McCullagh P, Nelder JA (1989) Generalized linear models, 2nd edn. Monographs on statistics and applied probability 37. Chapman \& Hall, London

Naud MJ, Lonf B, Brêthes JC, Sears R (2003) Influences of underwater bottom topography and geomorphology on minke whale (Balaenoptera acutorostrata) distribution in the Mingan Islands (Canada). J Mar Biol Assoc UK 83:1-8

Nordøy ES, Blix AS (1992) Diet of minke whales in the northeastern Atlantic. Rep Int Whal Comm 43:393-399

Ohsumi S, Masaki Y (1975) Biological parameters of the Antarctic minke whale at the virginal population level. J Fish Res Board Can 32:995-1004

Overholtz WJ, Nicolas JR (1979) Apparent feeding by the fin whale, Balaenoptera physalus, and the humpback whale, Megaptera novaeangliae, on the American sand lance, Ammodytes americanus, in the northwest Atlantic. Fish Bull Fish Wildl Serv US 77:285 - 287

Parsons ECM, Shrimpton J, Evans PGH (2000) Cetacean observations off northwest Scotland, perceived threats to cetaceans. In: Evans PGH, Cruz J, Raga JA (eds) European research on Cetaceans 13:128-133

Payne PM, Nicolas JR, O'Brien L, Powers KD (1986) The distribution of the humpback whale, Megaptera novaeangliae, on Georges Bank and in the Gulf of Maine in relation to densities of the sand eel, Ammodytes americanus. Fish Bull NMFS 84:271 - 277

Payne PM, Wiley DN, Young SB, Pittman S, Clapham PJ, Jossi JW (1990) Recent fluctuations in the abundance of baleen whales in the southern Gulf of Maine in relation to changes in selected prey. Fish Bull Fish Wildl Serv US 88: 687-696

Pingree RD, Maddock L (1985). Rotary currents and residual circulation around banks and islands. Deep Sea Res 32: $929-947$

Reay PJ (1970) Synopsis of biological data on North Atlantic sandeels of the genus Ammodytes: A. tobianus, A. dubius, A. americanus, and A. marinus. FAO Fish Synop 82:1-52

Reeves RR, Leatherwood S (1994) Dolphins, porpoises and whales. 1994-1998 Action Plan for the Conservation of Cetaceans. IUCN, Gland, Switzerland

Rice DW (1998) Marine mammals of the world: systematics and distribution. Spec Publ 4. Society for Marine Mammalogy, Lawrence, KS

Saville A, Bailey RS (1980) The assessment and management of the herring stocks in the North Sea and to the west of Scotland. Rapp P-V Réun Cons Int Explor Mer 177: 112-142

Schweder T, Hagen GS, Hatlebakk E (1998) On the effect on cod and herring fisheries of retuning the revised management procedure for minke whaling in the greater Barents Sea. Fish Res 37:77-95

Sigurjonsson J (1995) On the life history and autecology of North Atlantic rorquals. In: Blix AS, Walløe L, Ulltang $\varnothing$ (eds) Whales, seals, fish and man. Elsevier Science, Amsterdam, p 425-441

Simpson JH, Tett PB, Argotte-Espinoza ML, Edwards A, Jones KJ, Savidge G (1982) Mixing and phytoplankton growth around an island in a stratified sea. Contin Shelf 
Res 1:15-31

Skov H, Durink J, Danielsen F, Bloch D (1995) Co-occurrence of cetaceans and seabirds in the Northeast Atlantic. J Biogeogr 22:71-88

Stokin KA, Fairbairns RS, Parsons ECM, Sims DW (2001) Effects of diel and seasonal cycles on the dive duration of the minke whale (Balaenoptera acutorostrata). J Mar Biol Assoc UK 81:189-190

Tamura T, Fujise Y (2002) Geographical and seasonal changes of the prey species of minke whale in the North-

Editorial responsibility: Otto Kinne (Editor),

Oldendorf/Luhe, Germany western Pacific. ICES J Mar Sci 59:516-528

Whitehead H, Carscadden JE (1985) Predicting inshore whale abundance-whale and capelin off the Newfoundland coast. Can J Fish Aquat Sc 42:976-981

Woodley TH, Gaskin DE (1996) Environmental characteristics of North Atlantic right and fin whale habitat in the lower Bay of Fundy, Canada. Can J Zool 74:75-84

Wright PJ, Begg GS (1997) A spatial comparison of common guillemots and sandeels in Scottish waters. ICES J Mar Sci 54:578-592

Submitted: October 17, 2003; Accepted: May 11, 2004

Proofs received from author(s): July 30, 2004 